J. AMER. Soc. Hort. ScI. 117(3):384-388. 1992.

\title{
Brushing Influences Transplant Growth and Subsequent Yield of Four Cultivars of Tomato and Their Hybrid Lines
}

Tomio Johjima ${ }^{1}$

Faculty of Agriculture, Kagoshima University, Kagoshima 890, Japan

Joyce G. Latimer ${ }^{1}$

Department of Horticulture, Georgia Experiment Station, University of Georgia, Griffin, GA 30223

Hiroshi Wakita ${ }^{2}$

Faculty of Agriculture, Kagoshima University, Kagoshima 890, Japan

Additional index words. Lycopersicon esculentum, growth regulation, conditioning, mechanical stress

\begin{abstract}
Pot-grown seedlings of seven lines ['Red Cherry' (RC), 'Moneymaker' (MM), 'Dantobi-yohzu' (DY), 'Furikoma' $(\mathrm{FK}), \mathrm{RC} \times \mathrm{FK}, \mathrm{MM} \times \mathrm{DY}$, and MM $\times \mathrm{FK}$ ] of tomato (Lycopersicon esculentum Mill.) were brushed with a suspended steel bar for 1.5 minutes twice daily for 18 days (short-term treatment) before being transplanted to beds in a plastic greenhouse. Brushing was continued on a selected group of plants for an additional 10 days (long-term treatment). Short-term brushing slightly reduced the number of leaves, but markedly reduced leaf size and stem elongation of all lines. Dry weights of lamina, petioles, and stems of brushed plants of each cultivar except FK were less than those of the respective controls. However, the ratios of root : shoot dry weight of brushed plants were unchanged or higher than those of the respective controls. Short-term brushing did not increase the total number or weight of tomato fruits harvested over 1 month and did not improve fruit quality, size, or color. Long-term brushing reduced the total yield (number and weight) of fruits of RC and total fruit weight of DY. With respect to sensitivity to mechanical stress, cultivars with taller growth habits were more responsive to brushing than were those with shorter growth habits. These characteristic responses to mechanical stress also were exhibited by the hybrid lines.
\end{abstract}

Some effects of mechanically induced stress on the growth of plants are visible in the natural world. For example, trees exposed to strong wind develop shorter branches, smaller leaves, and a more compact crown than more protected trees and are capable of withstanding this stress for many years. If this principle is applied to the control of plant growth, it would be very useful for agricultural production. Many workers have examined the effects of mechanical stresses on various crops using different methods of treatment (Latimer, 1991).

Plants react to mechanical stress according to species (Akers and Mitchell, 1985; Latimer et al., 1986), cultivar, and growth habit (Latimer et al., 1986, 1991). Therefore, we have studied effects of mechanical conditioning on the growth of selected cultivars of various vegetable crops. Container-grown transplants of cucumber (Cucumis sativus L.), a climbing and axially flowering plant, exhibited good growth control in response to brushing with few subsequent reductions in fruit yield, but responses differed among the cultivars (Latimer et al., 1991). Mechanical stress inhibited the growth of tomato seedlings (Adler and Wilcox, 1987; Heuchert and Mitchell, 1983; Mitchell et al., 1975, 1977) and improved the mechanical strength and quality of the plants (Heuchert et al., 1983; Liptay, 1985). However, treatment effects on yield of these tomato plants were not determined. Mechanical stress increased the production of fe-

\footnotetext{
Received for publication 8 July 1991. Accepted for publication 16 Dec. 1991. Research completed at Kagoshima Univ. while J.G.L. was on leave as a visiting research' scholar under sponsorship of the Japan Sot. for the Promotion of Sci. Research supported by FY 1989 Monbusho Grant-in-Aid for Scientific Research (no. 01795025) from the Ministry of Education of Japan. The cost of publishing this paper was defrayed in part by the payment of page charges. Under postal regulations, this paper therefore must be hereby marked advertisement solely to indicate this fact.

Assistant Professor.

${ }^{2}$ Undergraduate Student. Present address: Vegetables and Fruits Section, UneedDaiei Co., Miyazaki 880, Japan.
}

male flowers of cucumber (Takahashi and Suge, 1980). Shortterm (10 days) shaking of tomato transplants decreased early, but not total, yields (Pardossi et al., 1988), while long-term shaking during crop production decreased their total yields (Buitelaar, 1989).

Therefore, we examined the effect of mechanical stress on tomato transplant growth. This report describes the effect of brushing on the growth and productivity of four cultivars of tomato, treated and grown under the protected environment of a plastic greenhouse. The objectives of this research were to determme if 1) brushing improves the compactness and quality of transplants, 2) brushing during transplant production (shortterm treatment) affects crop yield or fruit characteristics relative to those of undisturbed plants, and 3) additional (long-term) brushing, applied during transplant production and after planting but before fruit set, affects crop yield or fruit characteristics relative to undisturbed plants or to plants subjected to shortterm treatment. Differences in response by the cultivars and three hybrids to brushing also were noted.

\section{Materials and Methods}

For the growth responses of transplants, four cultivars of tomato and three hybrid lines were examined, including the determinate types DY and FK, the indeterminate types RC and $\mathrm{MM}$, and the hybrid lines $\mathrm{RC} \times \mathrm{FK}, \mathrm{MM} \times \mathrm{DY}$, and $\mathrm{MM} \times$ FK. DY and RC have long internodes and, therefore, long stems, whereas FK has short internodes and, therefore, a short stem. MM is considered to be intermediate in stem length. To test treatment effects on subsequent yield, only the four nonhybrid cultivars were used.

Seeds were pregerminated in a moistened gauze bag in a $30 /$

Abbreviations: DY, 'Dantobi-yohzu'; FK, 'Furikoma'; MM, 'Moneymaker'; RC, 'Red Cherry'. 
Table 1. Effect of short-term (18 days) brushing on growth of four cultivars and three hybrids of tomato grown in a plastic-covered greenhouse.

\begin{tabular}{|c|c|c|c|c|c|}
\hline $\begin{array}{l}\text { Cultivar and } \\
\text { treatment }\end{array}$ & $\begin{array}{l}\text { No. of } \\
\text { leaves }\end{array}$ & $\begin{array}{r}\text { Leaf } \\
\text { width } \\
(\mathrm{cm}) \\
\end{array}$ & $\begin{array}{c}\text { Leaf } \\
\text { length } \\
(\mathrm{cm})\end{array}$ & $\begin{array}{c}\text { Stem } \\
\text { length } \\
(\mathrm{cm}) \\
\end{array}$ & $\begin{array}{c}\text { Stem } \\
\text { diam } \\
(\mathrm{mm}) \\
\end{array}$ \\
\hline \multicolumn{6}{|l|}{$\overline{\mathrm{RC}}$} \\
\hline Untreated & $10.8 \pm 0.2^{y}$ & $14.6 \pm 0.3$ & $14.5 \pm 0.3$ & $32.1 \pm 0.7$ & $6.3 \pm 0.1$ \\
\hline Brushed & $10.2 \pm 0.2$ & $\underset{* * *}{12.5 \pm 0.3}$ & $11.4_{* * *}^{ \pm} 0.6$ & $22.5 \pm 0.5$ & $5.9 \pm 0.1$ \\
\hline \multicolumn{6}{|l|}{$\mathrm{MM}$} \\
\hline Untreated & $8.8 \pm 0.1$ & $15.3 \pm 0.4$ & $15.0 \pm 0.4$ & $27.2 \pm 1.0$ & $6.9 \pm 0.1$ \\
\hline Brushed & $\begin{array}{c}8.6 \pm 0.2 \\
\text { NS }\end{array}$ & $13.8 \pm 0.3$ & $12.4 \underset{* * *}{ \pm} 0.4$ & $19.0 \pm 0.8$ & $6.6 \pm 0.1$ \\
\hline \multicolumn{6}{|l|}{ DY } \\
\hline Untreated & $8.1 \pm 0.2$ & $18.7 \pm 0.4$ & $17.4 \pm 0.6$ & $27.7 \pm 0.7$ & $6.2 \pm 0.1$ \\
\hline Brushed & $\begin{array}{c}7.8 \pm 0.1 \\
\text { NS }\end{array}$ & $14.8 \underset{* * *}{ \pm} 0.3$ & $14.0 \pm 0.3$ & $19.2 \pm 0.3$ & $5.9 \pm 0.1$ \\
\hline \multicolumn{6}{|l|}{ FK } \\
\hline Untreated & $7.7 \pm 0.1$ & $13.5 \pm 0.6$ & $13.5 \pm 0.6$ & $9.6 \pm 0.5$ & $6.9 \pm 0.1$ \\
\hline Brushed & $\begin{array}{c}7.8 \pm 0.2 \\
\text { NS }\end{array}$ & $\begin{array}{c}12.6 \pm 0.5 \\
\text { NS }\end{array}$ & $\begin{array}{c}12.4 \pm 0.6 \\
\text { NS }\end{array}$ & $8.5 \pm 0.3$ & $\begin{array}{c}6.7 \pm 0.2 \\
\text { NS }\end{array}$ \\
\hline \multicolumn{6}{|l|}{$\mathrm{RC} \times \mathrm{FK}$} \\
\hline Untreated & $9.2 \pm 0.2$ & $14.2 \pm 0.4$ & $13.2 \pm 0.4$ & $27.4 \pm 0.4$ & $6.3 \pm 0.1$ \\
\hline Brushed & $\begin{array}{c}9.2 \pm 0.1 \\
\text { NS }\end{array}$ & $12.8 \pm 0.4$ & $12.0 \pm 0.4$ & $18.8_{* * *}^{ \pm} 0.2$ & $\begin{array}{c}6.3 \pm 0.1 \\
\text { NS }\end{array}$ \\
\hline \multicolumn{6}{|l|}{$M M \times D Y$} \\
\hline Untreated & $8.8 \pm 0.2$ & $17.4 \pm 0.3$ & $15.6 \pm 0.4$ & $31.3 \pm 0.8$ & $6.2 \pm 0.1$ \\
\hline Brushed & $\begin{array}{c}8.8 \pm 0.2 \\
\text { NS }\end{array}$ & $14.4_{* * *} 0.4$ & $12.8 \pm 0.6$ & $21.2 \pm 0.4$ & $\begin{array}{c}6.0 \pm 0.1 \\
\text { NS }\end{array}$ \\
\hline \multicolumn{6}{|l|}{$\mathrm{MM} \times \mathrm{FK}$} \\
\hline Untreated & $8.2 \pm 0.1$ & $15.1 \pm 0.2$ & $14.7 \pm 0.3$ & $28.1 \pm 0.5$ & $6.9 \pm 0.1$ \\
\hline Brushed & $\begin{array}{c}8.2 \pm 0.1 \\
\text { NS }\end{array}$ & $\begin{array}{c}14.2 \pm 0.5 \\
\text { NS }\end{array}$ & $12.5 \pm 0.4$ & $19.2 \pm 0.3$ & $6.6 \pm 0.1$ \\
\hline
\end{tabular}

${ }^{\text {z }}$ Stem diameter at $1 \mathrm{~cm}$ above the cotyledonary node. ${ }^{y} \mathrm{SE}$ of the mean.

Ns, **, *, "Main effects within cultivar not significant at $P=0.05$ or significant at $\mathrm{P}<$ $0.001,0.01$, or 0.05 , respectively.

22.C (day/night) incubator during late Mar. 1989. The pregerminated seeds were sown in rectangular plastic seed boxes filled with coarse sand $\approx 3 \mathrm{~cm}$ deep and covered with small (2- to 3$\mathrm{mm}$ particle size) volcanic rock. The seed boxes were loosely covered with clear polyethylene and placed back into the incubator. Ten days later, when the second true leaf was visible but not yet expanding, the seedlings were transplanted to 450$\mathrm{ml}$ polyethylene pots filled with a mixture of 3 coarse sand : 1 small volcanic rock $(\mathrm{v} / \mathrm{v})$. After being transplanted, the plants were grown in a plastic tunnel (for additional heat storage) in a plastic greenhouse and were fertilized with a balanced nutrient solution at each watering (Yamasaki et al., 1976). Treatments were assigned in a randomized complete-block design with four replications.

Treatments were initiated 8 days after the seedlings were transplanted to pots and were identical to those applied in previous studies (Latimer et al., 1991). Mechanical stress was applied by brushing the tops of plants with a hollow steel bar suspended in a polypropylene shade cloth sling attached to a frame built above the plants. The height of the bar was adjusted daily to brush the top 5 to $10 \mathrm{~cm}$ of the plants. Treatment was applied twice daily, 40 cycles (one back-and-forth stroke across the 90-cm-wide bed per cycle), at 0900 and $1630 \mathrm{HR}$ for 18 days. Each treatment lasted for $\approx 1.5 \mathrm{~min}$. Plants were gently watered overhead with a sprinkling can as required. Brushed plants were separated from controls by a guard row of plants.

After 18 days of treatment, plants of the four tomato cultivars were set by hand into the plastic house. The plastic house provided primarily temperature and rainfall protection during early spring, but the plastic sides of the house were raised to permit ventilation later in the season. Therefore, the plastic house did not eliminate wind-loading after planting. Transplants were planted in raised beds; previously fertilized (per $1000 \mathrm{~m}^{2}$ ) with $150 \mathrm{~kg}$ $\mathrm{CaCO}_{3}, 50 \mathrm{~kg} \mathrm{Ca}\left(\mathrm{H}_{2} \mathrm{PO}_{4}\right)_{2} \cdot \mathrm{CaSO}_{4}$, and $100 \mathrm{~kg}$ of a slow-release compound $(15 \mathrm{~N}-15 \mathrm{P}-15 \mathrm{~K})$; and covered with aluminum-coated polyethylene mulch $(0.03 \mathrm{~mm}$ thick). Plants were watered by a drip tube placed down the center of the row under the mulch. Plants were set $25 \mathrm{~cm}$ apart in 90 -cm-wide beds, two plants per bed width, in staggered rows. Medium in the beds consisted of 7 soil : 1 sand : 2 volcanic rock (by volume). Brushed transplants of the four cultivars were randomly assigned to either a short-term or a long-term treatment before being planted, three plants per treatment with three replications. Long-term treatment entailed continued brushing for an additional 10 days, after which time the plants were tied to stakes and handled according to normal cultural practices in Japan, wherein the primary stem of indeterminate lines was pinched back below the fifth inflorescence and all other lateral shoots were removed early during growth. For determinate lines, two shoots, the primary and secondary stems, were allowed to grow until four inflorescences had formed, at which time these stems were pruned above the fourth inflorescence. Other lateral shoots were removed as they formed.

Growth data collected at the end of the short-term brushing 
Table 2. Effect of short-term brushing on plant dry weight and its distribution (percentage of whole-plant dry weight) of four cultivars and three hybrids of tomato grown in a plasticcovered greenhouse.

\begin{tabular}{|c|c|c|c|c|c|c|c|c|c|}
\hline \multirow{2}{*}{$\begin{array}{l}\text { Cultivar and } \\
\text { treatment }\end{array}$} & \multicolumn{2}{|c|}{ Lamina dry wt } & \multicolumn{2}{|l|}{$\begin{array}{l}\text { Petiole } \\
\text { dry wt }\end{array}$} & \multicolumn{2}{|c|}{ Stem dry wt } & \multicolumn{2}{|c|}{ Root dry wt } & \multirow{2}{*}{$\begin{array}{c}\text { Root : shoot } \\
\text { ratio }\end{array}$} \\
\hline & (mg) & $(\%)$ & $(\mathrm{mg})$ & $(\%)$ & (mg) & $(\%)$ & (mg) & $(\%)$ & \\
\hline \multicolumn{10}{|l|}{$\mathrm{RC}$} \\
\hline Untreated & $390 \pm 77^{z}$ & 56 & $150 \pm 9$ & 6 & $570 \pm 26$ & 23 & $383 \pm 20$ & 15 & $0.18 \pm 0.01$ \\
\hline Brus & $\underset{* * *}{1050 \pm 36}$ & $\begin{array}{c}57 \\
*\end{array}$ & $104 \pm 4$ & $\begin{array}{c}6 \\
\text { NS }\end{array}$ & $\underset{* * *}{368 \pm 14}$ & $\underset{* * *}{20}$ & $313 \pm * 4$ & $\begin{array}{c}17 \\
*\end{array}$ & $0.21 \pm 0.01$ \\
\hline \multicolumn{10}{|l|}{ MM } \\
\hline Untreated & $1080 \pm 57$ & 55 & $138 \pm 7$ & 7 & $421 \pm 19$ & 22 & $307 \pm 24$ & 16 & $0.19 \pm 0.02$ \\
\hline Brush & $940 \pm 26$ & $\begin{array}{l}57 \\
*\end{array}$ & $111 \pm 4$ & $\begin{array}{c}7 \\
\text { NS }\end{array}$ & $\underset{* * *}{312 \pm 16}$ & $\begin{array}{l}19 \\
* * *\end{array}$ & $\begin{array}{c}275 \pm 11 \\
\text { NS }\end{array}$ & $\begin{array}{l}17 \\
\text { NS }\end{array}$ & $\begin{array}{c}0.20 \pm 0.01 \\
\text { NS }\end{array}$ \\
\hline \multicolumn{10}{|l|}{ DY } \\
\hline Untre & $1080 \pm 42$ & 55 & $136 \pm 6$ & 7 & $429 \pm 16$ & 22 & $329 \pm 20$ & 17 & $0.20 \pm 0.01$ \\
\hline Brus & $\underset{* * *}{806 \pm 39}$ & $\begin{array}{l}56 \\
\text { NS }\end{array}$ & $94 \pm 4$ & $\begin{array}{c}7 \\
\text { NS }\end{array}$ & $\underset{* * *}{284 \pm 9}$ & 20 & $261_{* *}^{ \pm} 17$ & $\begin{array}{l}18 \\
\text { NS }\end{array}$ & $\begin{array}{c}0.22 \pm 0.01 \\
\text { NS }\end{array}$ \\
\hline \multicolumn{10}{|l|}{ FK } \\
\hline Untre & $805 \pm 36$ & 62 & $78 \pm 4$ & 6 & $149 \pm 10$ & 11 & $273 \pm 18$ & 21 & $0.27 \pm 0.01$ \\
\hline Brus & $794 \pm 53$ & 63 & $72 \pm 5$ & 6 & $138 \pm 10$ & 11 & $252 \pm 17$ & 20 & $0.25 \pm 0.01$ \\
\hline & NS & NS & NS & NS & NS & NS & NS & NS & NS \\
\hline \multicolumn{10}{|l|}{$\mathrm{RC} \times \mathrm{FK}$} \\
\hline Untreated & $1150 \pm 58$ & 56 & $129 \pm 9$ & 6 & $424 \pm 19$ & 21 & $345 \pm 27$ & 17 & $0.20 \pm 0.01$ \\
\hline Brushed & $1150 \pm 58$ & 58 & $118 \pm 6$ & 6 & $349 \pm 16$ & 18 & $377 \pm 21$ & 19 & $0.23 \pm 0.01$ \\
\hline & NS & NS & NS & NS & $* *$ & $* * *$ & NS & * & $*$ \\
\hline \multicolumn{10}{|l|}{$M M \times D Y$} \\
\hline Untreated & $1210 \pm 48$ & 54 & $143 \pm 8$ & 6 & $533 \pm 16$ & 24 & $342 \pm 20$ & 15 & $0.18 \pm 0.01$ \\
\hline Brushed & $94 \underset{* * *}{9} 66$ & $\begin{array}{l}56 \\
* *\end{array}$ & $104 \pm 8$ & $\begin{array}{c}6 \\
\text { NS }\end{array}$ & $\underset{* * *}{362 \pm 31}$ & $\underset{* * *}{21}$ & $280 \pm 20$ & $\begin{array}{l}17 \\
\text { NS }\end{array}$ & $\begin{array}{c}0.20 \pm 0.01 \\
\text { NS }\end{array}$ \\
\hline \multicolumn{10}{|l|}{$\mathrm{MM} \times \mathrm{FX}$} \\
\hline Untreated & $1040 \pm 47$ & 55 & $126 \pm 6$ & 7 & $435 \pm 19$ & 23 & $291 \pm 19$ & 15 & $0.18 \pm 0.01$ \\
\hline Brushed & $\begin{array}{c}1050 \pm 42 \\
\text { NS }\end{array}$ & $\begin{array}{l}57 \\
* \\
\end{array}$ & $108 \pm 5$ & $\begin{array}{c}6 \\
* * \\
\end{array}$ & $347 \underset{* *}{ \pm} 17$ & $\begin{array}{r}19 \\
* * *\end{array}$ & $\begin{array}{c}327 \pm 19 \\
\text { NS }\end{array}$ & $\begin{array}{c}18 \\
*\end{array}$ & $0.22 \pm 0.01$ \\
\hline
\end{tabular}

${ }^{2} \mathrm{SE}$ of the mean.

Main effects within cultivar not significant at $P=0.05$ or significant at $P$ < $0.001,0.01$, or 0.05 , respectively

treatment included fresh and dry (after $72 \mathrm{~h}$ at $70 \mathrm{C}$ in a forcedair oven) weights of leaves, petioles, and stems; dry weight of roots (handwashed from media); and stem length and stem diameter (measured $1 \mathrm{~cm}$ above the cotyledonary node). Three plants per treatment were sampled from each of the four blocks. Red-ripe fruits of plants set in the plastic greenhouse were harvested twice weekly from 1 to 30 July and subjectively rated for visual quality. During early harvest, fruit dimensions were measured and fruit color was determined as the ratio a : busing the Hunter Lab scale of the color difference meter to evaluate treatment effects. Stem length between flower clusters was measured at the time of final harvest to evaluate long-term effects of treatments on plant growth. All data were subjected to analysis of variance using the general linear models procedure of SAS (Freund et al., 1986).

\section{Results and Discussion}

FK exhibited little growth response to short-term brushing; however, growth of the other six lines was significantly reduced by 18 ' days of brushing (Table 1). The number of leaves developing on treated plants generally was the same as that of controls, but leaf size of brushed plants of all lines, except FK, was reduced relative to that of the respective controls. Leaf length appeared to be more sensitive to brushing than was leaf width. Brushing reduced the stem length of these six lines by $\geq 30 \%$ relative to the respective controls, whereas stem growth of FK, a dwarf type, was only $10 \%$ less than that of the control.
Stem diameter of RC, MM, DY, and MM $\times$ FK was smaller than that of the respective controls. However, stem diameter was less affected by brushing than was stem length, as previously noted by Heuchert et al. (1983). All of the brushed transplants were of higher quality than untreated plants in that plant appearance was improved by an increase in greenness and better balance of leaf size with stem length (plant height). Also, fewer brushed plants were broken during manual planting.

Reductions in dry weights of lamina, petioles, and stems (Table 2) corresponded to reductions in leaf size and stem length (Table 1) of the respective lines at the end of short-term brushing. The dry weights of lamina, petioles, and roots of $\mathrm{RC} \times \mathrm{FK}$ and the dry weights of lamina and roots of $\mathrm{MM} \times \mathrm{FK}$ were similar for treated and control plants (Table 2), although leaf size was reduced by brushing (Table 1). Brushing these two hybrid lines increased the distribution of dry weight into roots; therefore, the ratios of root: shoot dry weights were higher than those of the controls. These two hybrids were indeterminate, long-stem types, so their growth habits were more similar to their maternal parents than to FK.

Stem dry weights were reduced by brushing in all lines except FK (Table 2). Brushing of the hybrids substantially reduced their stem length and dry weight, a response characteristic of the maternal lines. However, lamina dry weights of $\mathrm{RC} \times \mathrm{FK}$ and $\mathrm{MM} \times \mathrm{FK}$ were not significantly affected by brushing, a response also of FK, the paternal line. Although heritability of responses to mechanical stress has not been studied, these hy- 
Table 3. Effect of brushing on stem growth of four cultivars of tomato planted in a plastic-covered greenhouse.

\begin{tabular}{|c|c|c|c|c|}
\hline \multirow[b]{2}{*}{$\begin{array}{l}\text { Cultivar and } \\
\text { treatment }\end{array}$} & \multicolumn{4}{|c|}{ Stem length between each flower cluster $(\mathrm{cm})$} \\
\hline & $\begin{array}{c}\text { Below } \\
\text { first cluster }\end{array}$ & $\begin{array}{c}\text { From } \\
\text { first to second }\end{array}$ & $\begin{array}{c}\text { From } \\
\text { second to third }\end{array}$ & $\begin{array}{c}\text { From } \\
\text { third to fourth }\end{array}$ \\
\hline \multicolumn{5}{|l|}{$\mathrm{RC}$} \\
\hline Control & $43.3 \pm 0.4^{y} \mathrm{a}^{\mathrm{x}}$ & $18.8 \pm 0.2 \mathrm{a}$ & $21.2 \pm 0.2$ & $25.8 \pm 0.3 \mathrm{a}$ \\
\hline Short-term & $35.5 \pm 0.3 \mathrm{~b}$ & $19.7 \pm 0.1 \mathrm{a}$ & $23.3 \pm 0.6$ & $24.0 \pm 0.6 \mathrm{~b}$ \\
\hline Long-term & $29.6 \pm 0.1 \mathrm{c}$ & $16.1 \pm 0.3 b$ & $\begin{array}{c}21.2 \pm 0.1 \\
\text { NS }\end{array}$ & $23.0 \pm 0.7 b$ \\
\hline \multicolumn{5}{|l|}{ MM } \\
\hline Control & $42.4 \pm 0.5 \mathrm{a}$ & $20.7 \pm 0.5$ & $22.0 \pm 0.6$ & $18.2 \pm 0.8$ \\
\hline Short-term & $38.3 \pm 0.4 b$ & $21.8 \pm 0.2$ & $19.3 \pm 0.7$ & $18.4 \pm 0.1$ \\
\hline Long-term & $31.3 \pm 0.2 \mathrm{c}$ & $\begin{array}{c}18.1 \pm 0.6 \\
\text { NS }\end{array}$ & $\begin{array}{c}18.9 \pm 0.4 \\
\text { NS }\end{array}$ & $\begin{array}{c}21.5 \pm 0.3 \\
\text { NS }\end{array}$ \\
\hline \multicolumn{5}{|l|}{ DY } \\
\hline Control & $51.0 \pm 0.3 \mathrm{a}$ & $12.5 \pm 0.4 b$ & $17.7 \pm 0.7$ & $31.1 \pm 0.8$ \\
\hline Short-term & $44.9 \pm 0.3 \mathrm{~b}$ & $15.7 \pm 0.2 \mathrm{a}$ & $17.2 \pm 0.6$ & $34.9 \pm 1.0$ \\
\hline Long-term & $36.1 \pm 0.1 \mathrm{c}$ & $12.8 \pm 0.1 b$ & $\begin{array}{c}16.6 \pm 0.1 \\
\text { NS }\end{array}$ & $\begin{array}{c}31.8 \pm 0.5 \\
\text { NS }\end{array}$ \\
\hline \multicolumn{5}{|l|}{ FK } \\
\hline Control & $21.5 \pm 0.3$ & $7.7 \pm 0.0$ & $11.1 \pm 0.2 \mathrm{a}$ & $13.8 \pm 0.1$ \\
\hline Short-term & $20.0 \pm 0.0$ & $7.1 \pm 0.1$ & $11.4 \pm 0.2 \mathrm{a}$ & $13.3 \pm 0.1$ \\
\hline Long-term & $\begin{array}{c}19.9 \pm 0.1 \\
\text { NS }\end{array}$ & $\begin{array}{c}7.1 \pm 0.4 \\
\text { NS }\end{array}$ & $8.8 \pm 0.5 b$ & $\begin{array}{c}13.5 \pm 0.3 \\
\text { NS }\end{array}$ \\
\hline
\end{tabular}

${ }^{2}$ Determinate types, DY and FK, data shown are stem lengths below the first flower cluster of the secondary stem.

${ }^{y}$ SE of the mean.

${ }^{x}$ Mean separation within cultivar by LSD, $P=0.05$.

${ }^{\mathrm{NS}}$ Not significant at $\mathrm{P}=0.05$.

Table 4. Effect of brushing on total yield and fruit color of four cultivars of tomato grown in a plastic-covered greenhouse.

\begin{tabular}{|c|c|c|c|c|}
\hline $\begin{array}{l}\text { Cultivar and } \\
\text { treatment }\end{array}$ & $\begin{array}{c}\text { Total no. } \\
\text { fruits }\end{array}$ & $\begin{array}{c}\text { Total fruit } \\
\text { wt (kg) }\end{array}$ & $\begin{array}{c}\text { Mean fruit } \\
\text { wt }(\mathrm{g})\end{array}$ & $\begin{array}{c}\text { Fruit color }^{2} \\
(\mathrm{a}: \mathrm{b})\end{array}$ \\
\hline \multicolumn{5}{|l|}{$\mathrm{RC}$} \\
\hline Control & $44.6 \pm 0.2^{y} a^{x}$ & $1.08 \pm 0.05 \mathrm{a}$ & $24.3 \pm 1.2$ & $1.97 \pm 0.04 \mathrm{a}$ \\
\hline Short-term & $44.4 \pm 1.2 \mathrm{a}$ & $1.19 \pm 0.01 \mathrm{a}$ & $26.7 \pm 0.3$ & $1.83 \pm 0.03 b$ \\
\hline Long-term & $30.0 \pm 0.6 b$ & $0.73 \pm 0.03 b$ & $24.7 \pm 0.5$ & $1.85 \pm 0.01 b$ \\
\hline \multicolumn{5}{|l|}{ MM } \\
\hline Control & $18.3 \pm 0.5$ & $1.18 \pm 0.02$ & $64.7 \pm 2.0 \mathrm{a}$ & $2.00 \pm 0.02$ \\
\hline Short-term & $20.9 \pm 1.0$ & $1.24 \pm 0.04$ & $60.3 \pm 2.0 \mathrm{a}$ & $1.99 \pm 0.01$ \\
\hline Long-term & $19.7 \pm 1.0$ & $0.99 \pm 0.12$ & $49.3 \pm 3.8 b$ & $2.03 \pm 0.07$ \\
\hline & NS & NS & & NS \\
\hline \multicolumn{5}{|l|}{ DY } \\
\hline Control & $14.7 \pm 0.4$ & $1.24 \pm 0.01 \mathrm{a}$ & $84.3 \pm 2.6$ & $2.37 \pm 0.09 a$ \\
\hline Short-term & $14.1 \pm 0.9$ & $1.23 \pm 0.07 \mathrm{a}$ & $89.0 \pm 10.6$ & $1.89 \pm 0.05 b$ \\
\hline Long-term & $12.7 \pm 0.1$ & $1.00 \pm 0.06 \mathrm{~b}$ & $79.0 \pm 3.9$ & $2.07 \pm 0.16 \mathrm{~b}$ \\
\hline \multicolumn{5}{|l|}{ FK } \\
\hline Control & $14.2 \pm 0.1 b$ & $0.67 \pm 0.05$ & $47.3 \pm 3.5$ & $1.53 \pm 0.05 b$ \\
\hline Short-term & $17.9 \pm 0.2 \mathrm{a}$ & $0.83 \pm 0.08$ & $46.0 \pm 3.8$ & $1.69 \pm 0.05 \mathrm{a}$ \\
\hline Long-term & $13.3 \pm 0.2 b$ & $\begin{array}{c}0.73 \pm 0.03 \\
\text { NS } \\
\end{array}$ & $\begin{array}{c}55.3 \pm 3.0 \\
\text { NS } \\
\end{array}$ & $1.59 \pm 0.03 \mathrm{ab}$ \\
\hline
\end{tabular}

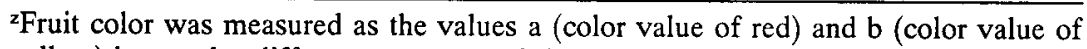
yellow) by a color difference meter, and the red hue $a: b$ is reported.

y $_{\text {SE }}$ of the mean.

${ }^{x}$ Mean separation within cultivar by LSD, $P=0.05$.

NSNot significant at $P=0.05$.

brids exhibit an optimal response to brushing: reduced stem length with no reduction in leaf dry weight and only moderate reductions in leaf size.

Tomatoes with long stems were more responsive to brushing, i.e., showed greater reductions in growth than the shorter or dwarf stem types. Some of the characteristic maternal and paternal features of the mechanical stress response were exhibited in the hybrid lines. Although Telewski and Jaffe (1986) found 
that stem elongation was the growth measurement most consistently affected by mechanical stress, there was very little difference in the response of 23 genetic half-sibs of Pinus taeda L. In our studies, the long internode stem type and the sensitivity of stem elongation to brushing were as evident in the hybrid lines $\mathrm{RC} \times \mathrm{FK}$ and $\mathrm{MM} \times \mathrm{FK}$ as in the maternal parents (Table 1), whereas the insensitivity of laminar dry-weight gain to brushing demonstrated by FK, the paternal parent, also was evident in the hybrids (Table 2). These results suggest that it may be possible to breed lines for various degrees of sensitivity to mechanical stress to fit various production programs.

Effects of brushing on stem length, measured between each flower cluster at the time of final harvest, were greatest below the first flower cluster of each plant, especially for plants treated with long-term brushing (Table 3). long-term brushing was discontinued when most plants had visible flower buds on the first cluster because they were physically damaged. Stem growth from the first to the second flower cluster of MM and FK was not significantly affected by brushing. However, stems (first to second flower cluster) of DY plants subjected to short-term brushing were longer than those of untreated plants, suggesting accelerated growth (Mitchell et al., 1975), whereas long-term brushing reduced the length of this stem region of treated RC plants. The effects of brushing on leaf size and stem diameter were similar to those on stem length (data not presented).

These data show that 18 days of brushing tomato transplants results. in reduced growth below the first flower cluster, but that brushed transplants grow vigorously after transplanting. Brushing for 10 days after transplanting (long-term treatment) more strongly retarded stem growth below the first flower cluster. This long-term mechanical stress affected growth of a sensitive cultivar (RC) between the first and second flower cluster as well. However, plants quickly recovered normal growth rates after the treatment ceased.

The mean interval to first flowering was 12 days after transplanting to beds in the plastic house for RC and MM and 16 days after transplanting for FK. Initial time required for flowering and the flowering dates of each successive cluster of these three cultivars were similar and unaffected by brushing. For DY, anthesis of the first cluster on plants subjected to longterm brushing was 9 days later than that of the respective control, which flowered 16 days after planting. A relatively long shaking treatment (> 30 days) delayed reproductive development of tomato (Akers and Mitchell, 1985). However, the time required for flowering of the upper clusters of DY was similar to that of controls (data not presented).

Physiological changes in response to mechanical stress (Hiraki and Ota, 1975; Suge, 1978) did not generally promote flowering or increase flower count of tomato plants as described for cucumber (Takahashi and Suge, 1980). However, short-term brushing increased flower count in the first and second clusters of FK and MM (data not presented), with a subsequent increase in the total number of fruits harvested from FK relative to the control (Table 4). In contrast, there were fewer flowers in the first and second clusters of RC and DY plants subjected to longterm brushing than in those of the respective controls (data not presented), and a corresponding decrease in yield. Long-term brushing reduced the total number and weight of fruits harvested from RC and the total weight of fruits from DY. We observed physical damage to $\mathrm{RC}$ flower buds present during the longterm brushing treatment, which probably contributed to the re- ductions in flower counts and total yield. The appearance and size (mean fruit weight) of fruits harvested from brushed plants generally were similar to those of the respective controls (Table 4). However, fruits of brushed RC and DY plants were less red ( $\mathrm{a}: \mathrm{b}$ ratio) than the respective controls.

In conclusion, mechanical stress, applied as a pretransplant brushing treatment, is an effective method of controlling the growth of tomato seedlings and of improving the quality and conditioning of the transplants. In cultural systems such as those found in Japan, where transplant production volume and greenhouse automation are both limited but the intensity of management is high, brushing provides an efficient growth management tool to produce high-quality transplants under common environmental conditions. However, we did observe differences in cultivar sensitivity to damage caused by brushing. DY exhibited leaf damage during the first 7 days of treatment, but hardenedoff to the treatment thereafter. Short-term brushing had no effect on crop yield, and there was no advantage to brushing after the transplants were planted. Brushing did not affect quality of tomato fruits or fruit size, but adversely affected color in some cultivars.

\section{Literature Cited}

Adler, P.R. and G.E. Wilcox. 1987. Salt stress, mechanical stress, or chlormequat chloride effects on morphology and growth recovery of hydroponic tomato transplants. J. Amer. Soc. Hort. Sci. 112:22-25.

Akers, S.W. and C.A. Mitchell. 1985. Seismic stress effects on reproductive structures of tomato, potato, and marigold. HortScience 20:684-686.

Buitelaar, K. 1989. Tomaat. Plantebeweging kan leiden tot lagere produktie. Groenten en Fruit 44(29):31 [Hort. Abstr. 59(9):7515;1989].

Freund, R.J., R.C. Littell. and P.C. .Spector. 1986. SAS system for linear models. SAS Institute, Cary, N.C.

Heuchert, J. C., J.S. Marks, and C.A. Mitchell. 1983. Strengthening of tomato shoots by gyratory shaking. J. Amer. Soc. Hort. Sci. 108:801-805.

Heuchert, J.C. and C.A. Mitchell. 1983. Inhibition of shoot growth in greenhouse-grown tomato by periodic gyratory shaking. J. Amer. Soc. Hort. Sci. 108:795-800.

Hiraki, Y. and Y. Ota. 1975. The relationship between growth inhibition and ethylene production by mechanical stimulation in lilium longiflorum. Plant Cell Physiol. 16:185-189.

Latimer, J.G. 1991. Mechanical conditioning for control of growth and quality of vegetable transplants. HortScience 26:1456-1461.

Latimer, J. G., T. Johjima, and K. Harada. 1991. The effect of mechanical stress on transplant growth and subsequent yield of four cultivars of cucumber. Scientia Hort. 47:221-230.

Latirner, J. G., T. Pappas, and C.A. Mitchell. 1986. Growth responses of eggplant and soybean seedlings to mechanical stress in greenhouse and outdoor environments. J. Amer. Soc. Hort. Sci. 111:694-698.

Liptay, A. 1985. Reduction of spindliness of tomato transplants grown at high densities. Can. J. Plant Sci. 65:797-801.

Mitchell, C. A., H.C. Dostal, and T.M. Seipel. 1977. Dry weight reduction in mechanically-dwarfed tomato plants. J. Amer. Soc. Hort. Sci. 102:605-608.

Mitchell, C.A., C.J. Severson, J.A. Wott, and P.A. Hammer. 1975. Seismomorphogenic regulation of plant growth. J. Amer. Soc. Hort. Sci. 100: 161165 .

Pardossi, A., F. Tognoni, and S.S. Lovemore. 1988. The effect of differnt hardening treatments on tomato seedling growth, chilling resistance and crop production in a cold greenhouse. Acts Hort. 229:371-378.

Suge, H. 1978. Growth and gibberellin production in Phaseolu.s vulgaris as affected by mechanical stress. Plant Cell Physiol. 19:1557-1560.

Takahashi, H. and H. Suge. 1980. Sex expression in cucumber plants as affected by mechanical stress. Plant Cell Physiol. 21 :303-310.

Telewski, F.W. and M.J. Jaffe. 1986. Thigmomorphogenesis: Anatomical, morphological and mechanical analysis of genetically different sibs of Pinus taeda in response to mechanical perturbation. Physiol. Plant. 6:219-226.

Yamasaki, K., Y. Suzuki, and Y. Shinohara. 1976. Studies on water culture of several vegetables with special reference to the control of nutrient solution and ratio of nutrients absorption per water consumption $(=n / w)$ (in Japanese, with English summary). Memoirs Faculty Agr., Tokyo Univ. of Ectucation, p. $53-100$. 